\title{
Run-out Distribution of Pasir Panjang Landslides Followed by the Debris Flow, Central Java, Indonesia
}

\author{
Imam A. Sadisun ${ }^{1,2}$, Indra A. Dinata ${ }^{1}$ and Rendy D. Kartiko ${ }^{1}$ \\ ${ }^{1}$ Applied Geology Research Group, Faculty of Earth Sciences and Technology, \\ Institut Teknologi Bandung, Indonesia \\ ${ }^{2}$ Research Centre for Disaster Mitigation, Institut Teknologi Bandung, Indonesia
}

Corresponding author: indraandradinata@gmail.com

\begin{abstract}
Indonesia is one of the world's most natural disaster-prone country from landslides. These landslides mostly occur at areas having steep to very steep slopes, intensive weathering processes and high to very high rainfall intensity. Generally, debris flows referred to mudflows or lahars. These types of landslide are common type of fast-moving landslide. In this regard, the occurrence of several landslides followed by the debris flow often make a lot of casualties and very terrible destructions in some areas of Java Island, Indonesia. For example, Jemblung Landslide on December 12, 2014 has 139 causalities. Accordingly, some debris flow modelling have been conducted to determine run-out distribution characteristics of debris materials at the depositional areas.
\end{abstract}

The concept of debris flow modeling is based on the equations of momentum, continuation, riverbed deformation and erosion/deposition and riverbed shearing stress. From the modeling of Pasir Panjang landslide case, the viscosity value of 0.38 indicated the best fit simulation result. The flowing material of this landslide case has very long distance, $2.3 \mathrm{~km}$ in approximate. It occurs because $275,295 \mathrm{~m}^{3}$ volume material which flowing is supported with $25.58 \mathrm{~km} /$ hour of maximum flow rate and relatively straight flow track in $35^{\circ}-45^{\circ}$ of slope angle.

Keywords: Landslide, debris flow, run-out modeling 